Conclusion: Cognitive impairment was common in both diseases but the cognitive domains affected were different. Rheumatologists should be aware of these differences when evaluating cognitive dysfunction in SLE and pSS patients.

References:

[1] Kurtuluş F, Çay H, Parlak E, Yaman A. Montreal cognitive assessment in primary sjogren's syndrome. A brief screening tool. Neurosciences. 2019;24(3):199-206.

[2] Tayer-Shifman O, Green R, Beaton D, Ruttan L, Wither J, Tartaglia M et al. Validity evidence supports the use of automated neuropsychological assessment metrics as a screening tool for cognitive impairment in lupus. Arthritis Care \& Research. 2019; .

Disclosure of Interests: None declared

DOI: 10.1136/annrheumdis-2020-eular.5894

\section{AB0411 COGNITIVE IMPAIRMENT IN PRIMARY SJÖGREN'S SYNDROME: A CASE-CONTROL STUDY}

M. J. Garza Martínez ${ }^{1}$, M. A. Treviño-Castro ${ }^{1}$, A. Cárdenas ${ }^{1}$, C. V. Solis ${ }^{1}$, R. Pineda ${ }^{1}$, J. C. Riegatorres ${ }^{1}$, C. M. Skinner Taylor ${ }^{1}$, D. Á. Galarza-Delgado ${ }^{1}$. ${ }^{1}$ University Hospital “Dr. José Eleuterio González”, Rheumatology, Monterrey, Mexico

Background: Neurological symptoms are common in primary Sjögren's syndrome (pSS) with a prevalence of 8.5 to $70 \%$, focusing on cognitive impairment, information in pSS is scarce.

Many neuropsychological tests are used to diagnose cognitive impairment. The Montreal Cognitive Assessment (MoCA) is a validated, practical, and reliable instrument for screening mild cognitive impairment.

Objectives: To evaluate the prevalence of cognitive impairment with the MoCA test in pSS and compare it with controls.

Methods: Patients of a rheumatology clinic in Northeastern Mexico were recruited, who met the pSS AECG 2002 or ACR-EULAR 2016 classification criteria. Controls, matched by demographic characteristics were included for comparison. All subjects took the MoCA. The test has a range of 0-30 points, the highest score reflects better cognitive function, and explores 6 cognitive domains (Table 2).

Table 1. Demographic and clinical characteristics

\begin{tabular}{lcc}
\hline Characteristics & $\begin{array}{c}\mathrm{pSS} \\
\mathrm{n}=51\end{array}$ & $\begin{array}{c}\text { Control } \\
\mathrm{n}=51\end{array}$ \\
\hline Age, Mean (SD) & $56(10.4)$ & $54(14)$ \\
Sex & $47(92.15)$ & $48(94)$ \\
Female $\mathrm{n}(\%)$ & $4(7.85)$ & $3(7.3)$ \\
Male $\mathrm{n}(\%)$ & $6.38(6.15)$ & \\
Disease duration (years), mean (SD) & $4.94(2.28)$ & $12(10-15)$ \\
ESSPRI mean (SD) & $13(10-17)$ & $29(56)$ \\
Years of education, median (q25-q75) & $19(37)$ & \\
Employment, mean (\%) & & \\
\hline
\end{tabular}

Table 2. MoCA subtest analysis by years of education in pSS and control group.

\begin{tabular}{|c|c|c|c|c|c|c|c|c|c|}
\hline & & $\begin{array}{c}\leq 9 \\
\text { years } 0 \\
\text { educa } \\
\text { tion }\end{array}$ & & & & $\begin{array}{r}\geq 10 \\
\text { years } \\
\text { educa } \\
\text { tion }\end{array}$ & & & \\
\hline & Group & $\mathrm{N}$ & mean, $\mathrm{SD}^{1}$ & $\begin{array}{l}\text { Min- } \\
\max \end{array}$ & $p$-value & $\mathrm{n}$ & mean, $\mathrm{SD}^{1}$ & $\begin{array}{l}\text { Min- } f \\
\max \end{array}$ & $p$-value \\
\hline \multirow[t]{2}{*}{ MoCA total } & pSS & 17 & $25.65(2.17)$ & 20 & 0.248 & 46 & $26.67(2.27)$ & ) 20 & 0.3 \\
\hline & Control & 14 & $24.36(3.85)$ & $\begin{array}{c}-29 \\
17\end{array}$ & & 36 & $27.22(2.24)$ & $\begin{array}{c}-30 \\
21\end{array}$ & \\
\hline \multirow[t]{2}{*}{ Visuospatial } & pSS & 17 & $3.76(0.9)$ & $\begin{array}{l}-30 \\
1-5\end{array}$ & 0.505 & 46 & $4.17(1.03)$ & $\begin{array}{l}-30 \\
2-5\end{array}$ & 0.056 \\
\hline & Control & 14 & 4.07 (1.59) & $0-5$ & & 36 & $4.58(0.87)$ & $2-5$ & \\
\hline Naming & $\begin{array}{c}\text { pSS } \\
\text { Control }\end{array}$ & $\begin{array}{l}17 \\
14\end{array}$ & $\begin{array}{l}2.82(0.39) \\
2.79(0.57)\end{array}$ & $\begin{array}{l}2-3 \\
1-3\end{array}$ & 0.831 & $\begin{array}{l}46 \\
36\end{array}$ & $\begin{array}{c}2.96(0.2) \\
2.97(0.16)\end{array}$ & $\begin{array}{l}2-3 \\
2-3\end{array}$ & 0.711 \\
\hline \multirow[t]{2}{*}{$\begin{array}{r}\text { Deyaled } \\
\text { recall }\end{array}$} & pSS & 17 & 3.06 (1.34) & $1-5$ & 0.251 & 46 & $3.48(1.31)$ & $0-5$ & 0.921 \\
\hline & Control & 14 & $2.43(1.65)$ & $0-5$ & & 36 & 3.44 (1.68) & $0-5$ & \\
\hline \multirow[t]{2}{*}{ Attention } & pSS & 17 & $5(0.79)$ & $3-6$ & 0.041 & 46 & $5.37(0.77)$ & $4-6$ & 0.285 \\
\hline & Control & 14 & $4.29(1.06)$ & $3-6$ & & 36 & $5.53(0.56)$ & $4-6$ & \\
\hline \multirow[t]{2}{*}{ Abstraction } & pSS & 17 & $1.71(0.68)$ & $0-2$ & 0.464 & 46 & $1.89(0.31)$ & $1-2$ & 0.79 \\
\hline & Control & 14 & $1.86(0.36)$ & $1-2$ & & 36 & $2(0.23)$ & $1-3$ & \\
\hline \multirow[t]{2}{*}{ Orientation } & pSS & 17 & $6(0)$ & $6-6$ & 0.999 & 46 & $5.93(0.25)$ & $5-6$ & 0.083 \\
\hline & Control & 14 & $6(0)$ & $6-6$ & & 36 & $6(0)$ & $6-6$ & \\
\hline \multirow[t]{2}{*}{ Language } & pSS & 17 & $2.41(0.71)$ & $1-3$ & 0.741 & 46 & $2.61(0.57)$ & $1-3$ & 0.878 \\
\hline & Control & 14 & $2.5(0.76)$ & $1-3$ & & 36 & $2.58(0.84)$ & $0-3$ & \\
\hline
\end{tabular}

${ }^{1} \mathrm{SD}:$ Standard deviation
We defined mild cognitive impairment as a score $<26$ and moderate-severe cognitive impairment as a score $<24$ as previously determined in Mexican population.

Results: Demographic and clinical characteristics are described in Table 1. Mild cognitive impairment was present in $13(25.4 \%)$ in pSS group versus $14(27 \%)$ in control group. Moderate-severe cognitive impairment was present in $9(17 \%)$ of pSS group versus $8(15 \%)$ in control ( $p>0.05)$.

Results of the individual domains and comparison between groups are shown in Table 2. Attention was lower in the pSS group with $\leq 9$ years of education compared to the control group ( $p<0.05$ ).

Conclusion: We did not found a difference in the prevalence of cognitive impairment, either mild or moderate-severe, in pSS subjects with low disease duration versus controls by MoCA. We found a lower attention score in the pSS group with less than 10 of years of education.

The combination of neuropsychological examining and imaging techniques, such as SPECT or brain MRI, seem a more sensitive way to detect cognitive impairment in earlier stages.

References:

[1] Manzo, C., Martinez-Suarez, E., Kechida, M., Isetta, M. and Serra-Mestres, J. (2019). Cognitive Function in Primary Sjögren's Syndrome: A Systematic Review. Brain Sciences, 9(4), p.85.

[2] Aguilar-Navarro S, Mimenza-Alvarado A, Palacios-García A, Samudio-Cruz A, Gutiérrez-Gutiérrez L, Ávila-Funes J. Validez y confiabilidad del MoCA (Montreal Cognitive Assessment) para el tamizaje del deterioro cognoscitivo en méxico. Revista Colombiana de Psiquiatría. 2018;47(4):237-243.

Disclosure of Interests: None declared

DOI: 10.1136/annrheumdis-2020-eular.4780

\section{\begin{tabular}{|l|l}
\hline AB0412 URINARY SOLUBLE VCAM-1 IS A USEFUL \\
\hline
\end{tabular} BIOMARKER OF DISEASE ACTIVITY AND TREATMENT} RESPONSE IN LUPUS NEPHRITIS

A. A. Gasparin ${ }^{1}$, N. Pamplona Bueno de Andrade ${ }^{1}$, V. Hax ${ }^{1}$, P. Palominos ${ }^{1}$, M. Siebert ${ }^{2}$, R. Marx ${ }^{1}$, P. Shaefer ${ }^{3}$, F. Veríssimo Veronese ${ }^{4}$, O. Monticielo ${ }^{1}$. ${ }^{1}$ Federal University of Rio Grande do Sul, Division of Rheumatology, Department of Internal Medicine, Porto Alegre, Brazil; ${ }^{2}$ Hospital de Clínicas de Porto Alegre, Biotechnology Centre, Porto Alegre, Brazil; ${ }^{3} \mathrm{Hospital}$ de Clínicas de Porto Alegre, Department of Pathology, Porto Alegre, Brazil; ${ }^{4}$ Federal University of Rio Grande do Sul, Division of Nephrology, Department of Internal Medicine, Porto Alegre, Brazil

Background: The traditional lupus nephritis (LN) biomarkers are not sensitive nor specific enough for detecting ongoing disease activity and early relapse of nephritis and they do not reflect kidney damage nor have prognostic value ${ }^{1}$. Urinary biomarkers are directly excreted by the kidney and are easily obtained. They can also differentiate the renal activity of the disease from other organic manifestations more accurately than the serum biomark$\mathrm{ers}^{2}$. Vascular cell adhesion molecule-1 (VCAM-1) is involved in the progression of glomerular and tubulointerstitial injury in LN and its soluble form can be easily assessed in urine $(\mathrm{UVCAM}-1)^{3}$. Several studies correlated the uVCAM-1 levels with urine protein-creatinine ratio (UPC), with general disease activity and with active $\mathrm{LN}^{3}$.

Objectives: To assess UVCAM-1 as a biomarker of disease activity and treatment response in LN.

Methods: This prospective study enrolled patients with class III, IV or V LN diagnosed within the last three years and divided them in two groups: with and without active nephritis at the inclusion. The patients with active nephritis were included before they started a new immunosuppressive treatment. Active $L N$ was defined as proteinuria (UPC $\geq 0.5$ ) plus active urinary sediment (hematuria, leukocyturia or cellular hematic/granular casts). At each visit, a urine sample was collected for UVCAM-1 evaluation and the nephritis status was accessed.

Results: Median uVCAM-1 level was elevated in patients with active compared to inactive $L N(p<0.001)$. The ROC curve of uVCAM-1 demonstrated an AUC of 0.84 and a cutoff of $47.2 \mathrm{ng} / \mathrm{mgCr}$ yielded a good sensitivity $(74.2 \%)$ and specificity $(74.2 \%)$ for the diagnosis of active LN. A significant correlation was found between UVCAM-1 level and renal activity scores and traditional biomarkers of LN (table 1). The level of UVCAM-1 dropped in patients with active $L N$ who went into remission $(p<0.001)$, increased in patients who went into activity $(p=0.002)$ and did not change in patients who remained inactive $(p=0.797)$ (figure 1$)$. The level of $\mathrm{UVCAM}-1$ peaked during the flare of LN $(p<0.05)$ (figure 2). 